\title{
Practical Teaching \& Learning Model: A Modern Dimension for Business Management Schools
}

\author{
Nadir Ali Kolachi ${ }^{1}$ \\ ${ }^{1}$ Skyline University, University City of Sharjah, UAE \\ Correspondence: Nadir Ali Kolachi, Skyline University, University City of Sharjah, UAE. E-mail: \\ nadir.kolachi@gmail.com
}

Received: February 9, 2013 Accepted: March 11, $2013 \quad$ Online Published: May 2, 2013

doi:10.5539/jel.v2n2p108

URL: http://dx.doi.org/10.5539/jel.v2n2p108

\begin{abstract}
Purpose: The purpose of this research is to evaluate and investigate the most suitable model required for teaching business Management curriculum. The paper will report a new dimension of Business Management Teaching. For this purpose, a Practical teaching \& Learning Model has been prepared and will be discussed through qualitative research approach. The research proposed a model for Practical Teaching named PTLM (Practical Teaching \& Learning Model). The model explains the ways for Business Management Faculty \& Students in order to learn more during studies.

Research Design: The study reports on a practical qualitative case study limited to business management domain. The choice of this approach was convenient \& suitable.

Practical implications: The practical implication of this study is to identify the parameters of Business Management Teaching mentioned in the proposed model named PTML. The paper is academic based on practical case study approach and will benefit students, teachers, researchers and corporate trainers from business management fields.
\end{abstract}

Keywords: business management teaching, business management students, practical \& learning applications

\section{Introduction}

There has been a gap between Teaching \& Practical Teaching since business education evolved long time ago. Some people focused on just teaching through books, some maintained just experiential approach while other maintained both of them but uniformity was always missing. This research has found the gap through the proposed model which will not only fill the gap but also provide a proven method for a real business management environment. This research paper has analyzed different methods of teaching $\&$ learning and found that most of the models are incomplete or difficult to adopt. The purpose of this is to present a model which is easy to adopt, possess required elements of practicality and compatible for both teachers and students. Business management Education is a platform that prepares people to help corporations towards success. This also helps people to learn professional skills required for today's corporate managers. This research will identify the factors which must be included while teaching management sciences to make management sciences through real managerial exposure which is required for such practical studies.

Teaching Business Management has always been in discussion specially what kind of method should be followed, the method which may ensure a learning. Business teaching becomes practical when it is delivered and learned through practical participation from both teacher and students. Technically, the purpose of business education is to prepare students to solve company's problems. This can be achieved when some situations occurred in the past and teachers record this in understandable format for the students and students may do the same on their own analysis. Students must be evaluated by any of the leadership in the university. This ensures that students are capable enough to handle situation. This is achieved through different projects, role playing and defense of the projects. Students must be participant in all activities specially the type of comparative management and Harvard National Model United Nations (HNMUN) Model styles which give students a sense of understanding at macro level. This definitely enhances the leadership capability. Just teaching in class room will never ensure to prepare students at 360 levels. Just being teacher will also not prepare a faculty to be a good corporate style institutes. This is possible through various forces of development. The regular feature of 
conferences, workshops and symposiums will enhance such capabilities of students and teachers.

\section{Business Management Teaching}

- Teaching by way of case studies

- $\quad$ Evaluating Students by way of managerial \& leadership styles

Table 1. Business management faculty

\begin{tabular}{|c|c|}
\hline $\begin{array}{l}\text { Practical Teaching } \\
\text { (For Business Management Faculty) }\end{array}$ & $\begin{array}{l}\text { Practical Learning } \\
\text { (For Business Management Students) }\end{array}$ \\
\hline $\begin{array}{l}\text { 1. Advising, Caring, , Mentoring \& Training } \\
\text { 2. Emotional Stability, Humble, Interactive \& } \\
\text { Following up }\end{array}$ & $\begin{array}{l}\text { 1. Disciplined, Focused, Honest \& Loyal } \\
\text { 2. Motivating, Opportunistic, Positive \& } \\
\text { Responsible }\end{array}$ \\
\hline $\begin{array}{l}\text { 3. Knowledgeable, Neutral, } \\
\text { Responsible }\end{array}$ & $\begin{array}{l}\text { 3. Patient, Optimistic, Corporate Behavior \& } \\
\text { Dignity }\end{array}$ \\
\hline $\begin{array}{l}\text { 4. Researcher, Corporate } \\
\text { Respecting \& Paternalistic }\end{array}$ & $\begin{array}{l}\text { 4. Smart, Visionary, Winner \& Ambitious } \\
\text { driven }\end{array}$ \\
\hline Intellectual & Corporate leader \\
\hline Commitment & Organizational Development Consultant \\
\hline
\end{tabular}

Achieving intellectual capability and committed behavior of faculty is possible through four above points mentioned on business management side in the model. Achieving being corporate leader and behaving as OD consultant, students must be emphasized, trained and instilled all above four points mentioned on business management students side in the model. The middle section of this model is the crux of whole research which explains how practical teaching can be maintained by teachers and how practical teaching can be achieved by students. Both categories are further divided into four subheading comprising on further four sub topics each at both sides. The purpose of doing so is to research the ideas and put as a guide line for business education purposes. Practical advising is to update where is the business going, what is the trend of the companies, what must be focused and what should be changed in the coming time. Practical caring is deciding what is good for the student at the moment, so that he can be guided properly. Practical mentoring \& training is to continuously guide students showing videos, role playing, competitive assignments. Practical teaching is done by teachers who possess high emotional stability which means teachers solve the students' problems without any displeasure or anger, care and solve everything through humble and interactive way. Later on follow it, how much is achieved what to do next? Practical teachers are constantly explorer, neutral in comments, show very optimistic ways and teach responsibility \& accountability. The other side becomes easy after witnessing high level of input from business management faculty. Practical learning is practical when someone follows all disciplined and focused projects, show high level of loyalty. This motivates them to be responsible. Practical learning is active learning, whatever students have learned, they are going to apply and they are going to behave that way. This huge work on teaching \& learning will create intellectual pool of students. Good students will enter the corporate world with high level of commitment to show the corporate leader behavior and start working on the change management development model in order to move the corporations towards the right direction.

\section{Literature Survey}

There is much literature based on empirical and suggestive studies on business education and teaching styles but very few on teacher \& leader as producing future leaders but now due to the magnitude on such theories and faster flow of business education trends have created enough room to carry on research \& development. This particular study is also suggestive model for business teachers to become leaders and help themselves to adopt practical learning. Universities are in great need of organizational learning environment. Organizational learning refers to the process of improving organizational behaviors by acquiring and developing new knowledge \& capabilities (Fiol \& Lyles, 1985). Knowledge is also continuous (March \& Olsen), 1976. Universities must create facilitative platform for faculty and balanced work on teaching. Heavy teaching load, community based research and many other responsibilities do result in stress (Fuhrmann, B., 1994; Goodwill, 1970; Spaights, 1980). This needs to be checked by HEC authorities. The practical platform for faculty and student is to maintain 
open communication. Open communication has long been considered as important element in faculty culture (Austin 1990, Millet 1962). It facilitates the creation of a congenial and sympathetic company of scholars in which friendships, good conversation and mutual aid can flourish (Bowen \& Schuster, 1986; p. 55). Conversely, where communication is constrained, faculty may feel isolated from colleagues \& alienated from their work. (Linholm, 2003; Tierney Bensimon, 1996). Above literature points support the facilitative platform for students and faculty.

Universities are real processes where they facilitate student \& faculty for industry visits. Universities are primary places of education, research and creation of new knowledge and are crucial actors in the innovation of knowledge based societies and promotion of economic development, in synergy with institutions \& industries (Etzkowitz, 2004).

\section{Analysis of Practical Teaching through Input, Process and Output Ways}

Practical teaching is a responsibility and practical learning is accountability. Both have ethical factors which need to be checked at various levels. Practical teaching is an art which is in the eyes of practical teacher while practical learning is a science which is based on the learning experience in varied fields. Practical Teaching is dependent on University \& Students. Following is the explanation of Practical teaching as Input, University as Process and Students as an Output.

- Input

○ Teaching, Training, Advising \& Motivating

- Process

- Professional Development \& Grooming, Active Learning and Applications

- Output

- Corporate Leader, A University Product, and Level headed Behavior.

Above process is very sensitive in nature for the researcher. Generally, the positive way look very general and some universities follow only on the two points and believe that they are achieving everything. This process emphasizes that all the above points must be followed sequentially as it is followed by Harvard, IIM and LUMS. The commonality of such universities is that they first focus on the input, the teacher, they create high facilitative platform for the teacher (process) and later on they expect the graduates to be acceptable corporate leaders. This way, the University also maintains good control on academic and professional activities. Practical teaching has always been in question and discussion. This research brings into notice of such issues through PTLM model and this particular process from input to output.

\section{Research Methodology}

This is case study research method based on the practical viewpoints of the author. The model is developed through primary sources, priori knowledge of the author and some expert opinion from secondary sources literature. The objective of this study is to evaluate, find and propose the practical model for business management faculty in order to make it more competitive and learning based. Some of the scope of this study is found on business management faculty \& learning model. The methodology of exploratory and case based was convenient and adopted. Data collection method was based on primary, author's interest, secondary, interviews, facebook and was analyzed through qualitative and case based instructions.

\section{Conclusion}

This research concludes that the gap of incompetency in Management Teaching can be followed through practical management teaching as proposed in the model. The model believed to be more effective in having better results of producing quality business graduates.

\section{Recommendations}

- Universities are supposed to initiate training sessions for understanding the practical teaching and learning through the parameters mentioned in the PTLM model

- Universities conduct surveys of identifying practical models and compare other universities' competitive methodology in order to produce competitive students

- All management courses should be aligned with PTLM model proposed in this research. 


\section{References}

Austin, A. (2002). Preparing the next generation of faculty. Journal of Higher Education, 73(1), 94-122. http://dx.doi.org/10.1353/jhe.2002.0001

Bowen, H., \& Schuster. (1986). American professors. A national resource imperiled Newyork.

Fiol, C. L. (1985). Organizational Learning. Academy of management Review, 10, 803-813.

Fuhrmann, B. (1994). Leadership issues for faculty. Metropolitan Universities, 71-77.

Linholm, J. (2003). Perceived organizational fit, nurturing the minds, hearts \& personal ambitions of university faculty. Review of Higher Education, 125-149. http://dx.doi.org/10.1353/rhe.2003.0040

Millet J. (1962). The Academic community. Newyork McGraw Hill. 